\title{
MORAL VALUES OF EARLY ADOLESCENTS: CONATIVE LEVEL
}

\author{
Snieguolè Vaičekauskienè \\ Lithuanian University of Education, \\ National Agency for School Evaluation, Lithuania
}

\begin{abstract}
The most intensive education of moral values takes place in adolescence, and thus the family and school have to make big efforts for the internalization of moral values. The article reviews the opinions of teachers and parents of $5-6^{\text {th }}$ grade pupils and analyses the conative (behaviour) level of moral attitudes among early adolescents. The survey showed that early adolescents are self-critical; they assess their moral behaviour stricter than the behaviour of their peers, whereas the teachers assess the moral behaviour of teenagers stricter than pupils or their parents.
\end{abstract}

Keywords: attitudes, morality, school, teenager, values.

\section{Introduction}

Globalization has a positive effect on economic well-being, however it is also often considered to be the source of all modern evils (human vices). Technological, economic, social, political, cultural and education developments bring about changes of values in the society. The $21^{\text {st }}$ century sees a rapid development of technologies and economics, the change of climate. Lithuania's Progress Strategy 2030 states that it is difficult to foresee what technologies will prevail in the future, what influence they will make on our life and what will guarantee our success and wellbeing. Yet there are things that change little through ages and they also determine the societal development. These things are moral values that characterize the core of individual's wellness and regulate human life in a non-violate manner (Aramavičiūtè, Martišauskienè, 2009).

Globalization has created doubts whether moral values are acceptable and obligatory to all human beings (Bauman, 2007). Moral values of modern teenagers are doubted especially frequently as stressful emotions and instincts common in this age manifest wildly (Steiner, 1996) and different experiences are perceived with great emotions. Structuring, classifying, hypothesizing, abstract thinking abilities develop in adolescence, therefore this period is beneficial for the internalization of values: teenagers are avid consumers of spiritual and material values, while their consciousness becomes very open to the variety of culture forms (Astra, 1993). If "conditions for internalization of moral values are not created in adolescence, material and mercantile values take over and prohibit the uniting of people and mankind, increase the occurrence of destructive behaviours" (Martišauskienè, 2011, p. 54). Knowledge about values received by teenagers performs the function of moral attitude cognition and 
formation; the attitudes change through knowledge systematization and interpretation. Attitude is "more or less crystalized position of the subject (individual or collective) towards the object (person, group, situation, value); it is expressed more or less openly through various symptoms and indicators (presence or absence of words, tone, gestures, actions)" (Maisonneuve, 1973, p. 111). Formed attitudes are recognized in the person's actions and behaviour; therefore researchers who analyse the moral development of humans most often base their considerations on the expression of this component.

However, the division of the construct of attitude into different components (cognitive (intelligence, knowledge), affective (emotions), and conative (practical activity)) is relative because all components are interdependent and the "function of attitude is at the same time cognitive, energetic and regulating" (Maisonneuve, 1973, p. 111). Some components of attitude dominate over the other depending on the situation, setting and preparedness of the person, free and voluntary disposition to act in one way or another. Cognitive and emotional levels are important for education, whereas the society is interested in the behaviour of its members (only the third conative component of attitude). The society is not very interested in attitude development mechanisms: the society expects appropriate behaviour from teenagers, i.e. such education outcome that subsequently would become character traits (Havard, 2014).

Moral education has received increased interest from researchers. Moral education is discussed from different aspects of education theory and practice: the roots of moral education, expression and development in sport activities (Budreikaite, 2014), by highlighting separate values, such as dignity, humanity (Bakutyte, 2001), relation between spiritual and artistic education (Girdzijauskas, 2008), by solving sexual education problems in teenagers and youth (Donovan, 1998; Ruškus, Sujeta, 2011), viewing the moral education of youth as an exceptional integrative phenomenon of a person's spiritual development (Aramavičiūte, Martišauskienè, 2014), viewing the surrounding environment as a significant factor of education (Thapa et al., 2013). V. Aramavičiūtė ir E. Martišauskienè (2014) are the key researchers who study moral education of youth and teenagers in Lithuania. Studies of US psychologists, education scientists, leadership experts and researchers of other fields are distinguished from foreign sources: teenager personality development assessment instruments based on positive psychology are introduced, factors influencing personality development are discussed (Hilliard et al., 2014; Lerner et al., 2005), looking into the depths of the human spirit is encouraged (Covey, 2008 et al.).

Literature review revealed that researchers seldom analyse and compare the attitude of educators (teachers and parents) and teenagers to moral behaviour. Therefore the article delves into the following scientific problem: what characteristics of moral behaviour of teenagers are seen as most / least frequently occurring by early adolescents, their parents and teachers, how 
congruent are their views and how can they affect the development of moral values.

Goal: highlight the conative expression of moral values in modern teenagers of early adolescents.

\section{Objectives:}

- Discuss the authenticity, responsibility and dignity, as the core of moral values education in early adolescents;

- Highlight the characteristics of empirical expression of authenticity, responsibility and dignity towards others in early adolescents;

- Compare the attitudes of $5-6^{\text {th }}$ graders, their parents and teachers towards the moral behaviour of pupils.

The theoretical approach of the study is based on: the concept of holistic education (Bitinas, 2000; Hattie, 2014) stating that a child develops as an integral personality, and education process is a unified system; the ideas of existential philosophy and humanistic education (Lepeškienè, 1996; Lukšienè, 2000; Maceina, 2005; Rogers, 2005) urging to educate a free, responsible, righteous, authentic and broadly educated personality.

Survey sample. The survey involved $5-6^{\text {th }}$ graders $(n=1036)$, their parents $(n=405)$ and teachers $(n=61)$ from 14 secondary schools in different Lithuanian towns and regions. The pupils were invited to participate in the survey using the probability sampling method and improved serial sampling form (Kardelis, 2002, p. 121).

Research methods: theoretical (scientific literature and document analysis), empirical (survey in writing) and statistical (calculation of frequencies).

\section{Authenticity, responsibility and dignity as the core of moral development}

The development of mature personality is related with moral values: "being a moral person means thinking morally and behaving appropriately" (Myers, 2000, p. 112). Many theologians, philosophers, and researchers in other areas of education science (Arendt, 1995; Colombero, 2001; Covey, 2007 et al.) note the importance of moral values in the life of modern people and development of today's society that lives "in the period of "soul freezing spiritual decline" (Virbaliene, p. 121). Besides, the researchers have noted that "the attitudes of modern teenagers to moral values only partly respond to the challenges of today, and the trend of declining acceptance of spiritual values such altruism, responsibility, delight, intelligence, faith, adjustment of interests, creativity etc. raises education problems, the solution of which cannot be delayed" (Martišauskienè, 2011, p. 52).

National strategic documents define the key values (openness, responsibility creativity) that form the basis of our country's vision "to become a modern energetic country, embracing differences, and with a strong sense of 
national identity (Lithuania's Progress Strategy 2030). Globalization and knowledge era encourage to value creativeness (used when speaking about a human being) and creativity (used when speaking about human works or his/her real actions (Grammar of the Lithuanian language, 1997)). The necessity to prepare for changes and the ability to act creatively both under usual and new conditions is highlighted in the modern society. According to M. W. Martin (2006), "creativity is a morally valuable newness. It does not mean that we have to invent virtues "starting from zero", but new ideas and activities must be based on the key moral values; we have to support moral ideals that help to find the answer in ambiguous situations" (p. 56). This understanding is relevant in our changing world, where we often have to choose between spiritual and material values. Creation, as the highest expression of the human spirit, may help a man to objectively assess the situation and choose correctly, to remain authentic without undermining one's moral ideals.

Researchers have noted that change affects various spheres of public life: it embraces the openness to other cultures and their values; on the other hand change may become the cause of value tension prompting to learn more tolerance. Every human being is unique and this uniqueness is expressed through the authenticity of free and self-determined choices. A human being strives for self-expression, disclosing own potential and skills, internal constructive creativity. By acting creatively a human being can successfully face the increasing flows of information, solve problems effectively and responsibly, make authentic choices.

Authentic moral decisions based on accumulated knowledge and experiences enable to change culture, to overcome superficiality and insincerity. T. Lileikiene (2004) has noted that creativeness is preconditioned by personal freedom and curiosity, initiative, originality and activity stemming from this freedom. The growing feeling of identity at the late stage of adolescence excites creative power that enables to reflect the relations with others and self and create them anew. According to R. Laužackas, E. Stasiūnaitienè and M. Teresevičienè (2005), reflective thinking helps to move from the blind trust in authorities to reflection, critical assessment of knowledge, argumentation and explanation of own viewpoint. K. Urban (2003) noted that a teacher, who fosters creativeness, creates a learning environment based on openness and freedom, encourages flexibility and original thinking, provides conditions for the pupils to experiment, to act independently and accept themselves positively. In summary of research findings, we may state that creativeness and authenticity may be considered as moral values. Nevertheless, the boundary between moral and immoral creativeness and authenticity must be felt. Creativeness, authenticity, like other values are seen the best in everyday activities: the actual spirituality reveals not in extraordinary situations but "in ordinary situations when a person does not do anything outstanding or interesting $<\ldots>$, from his attitude to usual things, when he does not receive attention from others" (Chambers, 2011, p. 96). 
Moral behaviour may be influenced by the level of self-esteem and respect to others. Researchers (Kaplan 1980, 1986; Scott, 2004 et al.) have noted that teenagers with low self-esteem and negative experience show little respect and tolerance to others. Intensive development of personality starts in the middle childhood. There is no single and universal model of the learning environment that fits to all - all humans are different; however, everybody needs an open and enabling environment. R. Florida (2001) gives significance not to knowledge or academic achievements, entrepreneurship or financial success that result from creative thinking, but to pleasant, relaxing and natural environment, traditional values and institutional culture. Aristotle said that tolerance and apathy are the last virtues of a dying society. Therefore, moral attitudes shall be developed with great attention to human dignity (development of respect, self-esteem, tolerance), humane learning environment, where the child gradually matures by creatively and authentically interpreting knowledge, assessing it emotionally and rationally, being aware of the moral self (Taylor, 1996, p. 37), being open, trusting others and oneself, reflecting and finding moral essence in his/her feelings, relations and activity; such a child is able to combine personal and social expectations and values. These things have an influence on self-image and self-compassion (Slee, 2002).

In the era of information technologies self-image of often formed in public while teenagers communicate in social networks and openly share almost all details of personal life and experiences. Studies in different disciplines (Heideher, 1989; Levi-Strauss, 1994 et al.) show that openness and responsibility have influence on the specific individual as well as on the entire organization; however researchers emphasize a responsible (moral) way of life where responsibility, conscientiousness, resilience come to the fore. Development of authenticity, responsibility and dignity (Table 1) in teenagers means caring about the consistency and value of their moral behaviours.

The analysis of the findings of research in different disciplines and fundamental values highlighted in Lithuanian strategic documents revealed the core values to be focused on in education. The expression and empirical characteristics of these values were defined (Table 1) and used in the diagnostic survey described in this article. The survey aimed to show the expression of moral values - authenticity, responsibility and dignity - in everyday life of early adolescents. 
SOCIETY. INTEGRATION. EDUCATION. Volume II

Table 1. Moral values and their teaching curriculum

\begin{tabular}{|c|c|c|}
\hline Values & Expression & Empirical characteristics \\
\hline \multirow{6}{*}{$\begin{array}{l}\text { Authenticity } \\
\text { of moral } \\
\text { choices / } \\
\text { decisions }\end{array}$} & \multirow[t]{2}{*}{ Personhood } & $\begin{array}{l}\text { Awareness of moral self, learning to know and feel } \\
\text { the self }\end{array}$ \\
\hline & & $\begin{array}{l}\text { Relating own behaviour and behaviour of others } \\
\text { with moral values }\end{array}$ \\
\hline & \multirow[t]{2}{*}{ Openness } & Trust in others \\
\hline & & Trust in self \\
\hline & \multirow[t]{2}{*}{ Reflectivity } & $\begin{array}{l}\text { Ability to discern the moral sense of own feelings, } \\
\text { relationships with others }\end{array}$ \\
\hline & & Basing behavioural changes on reflection \\
\hline \multirow[t]{6}{*}{ Responsibility } & \multirow[t]{2}{*}{ Responsibility } & Timely completion of tasks and commitments \\
\hline & & Keeping promises \\
\hline & \multirow[t]{2}{*}{ Conscientiousness } & Not telling lies, doing the right thing \\
\hline & & Admitting own mistakes \\
\hline & \multirow[t]{2}{*}{ Resilience } & Overcoming the temptation to break moral rules \\
\hline & & Self-control in moral conflicts \\
\hline \multirow[t]{6}{*}{ Dignity } & \multirow[t]{2}{*}{ Respect } & $\begin{array}{l}\text { Appreciating the merits of others, admiring their } \\
\text { work }\end{array}$ \\
\hline & & Behaving positively and respectfully towards others \\
\hline & \multirow[t]{2}{*}{ Self-esteem } & Feeling own worth, self-acceptance \\
\hline & & $\begin{array}{l}\text { Not attempting to please others, looking for } \\
\text { solutions that do not undermine own and others' } \\
\text { dignity }\end{array}$ \\
\hline & \multirow[t]{2}{*}{ Tolerance } & Respecting opinions and choices of others \\
\hline & & Believing in the kindness and honesty of others \\
\hline
\end{tabular}

\section{Behaviour of early adolescents in terms of authenticity, responsibility and dignity}

The attitude of teenagers to authenticity, responsibility and dignity was studied by using two blocks of items: one block consisted of 18 items corresponding to the empirical characteristics of the three moral values (see Table 1) and the respondents were asked to rate them by importance to a good friend; the second block consisted of 24 items and the respondents had to rate them according to the frequency of behaviour described in the statement (in the block of 24 items 18 statements corresponded to the empirical characteristics of authenticity, responsibility and dignity, and 2 statements were ambivalent). The survey data are summarized in Figures 1 and 2. 


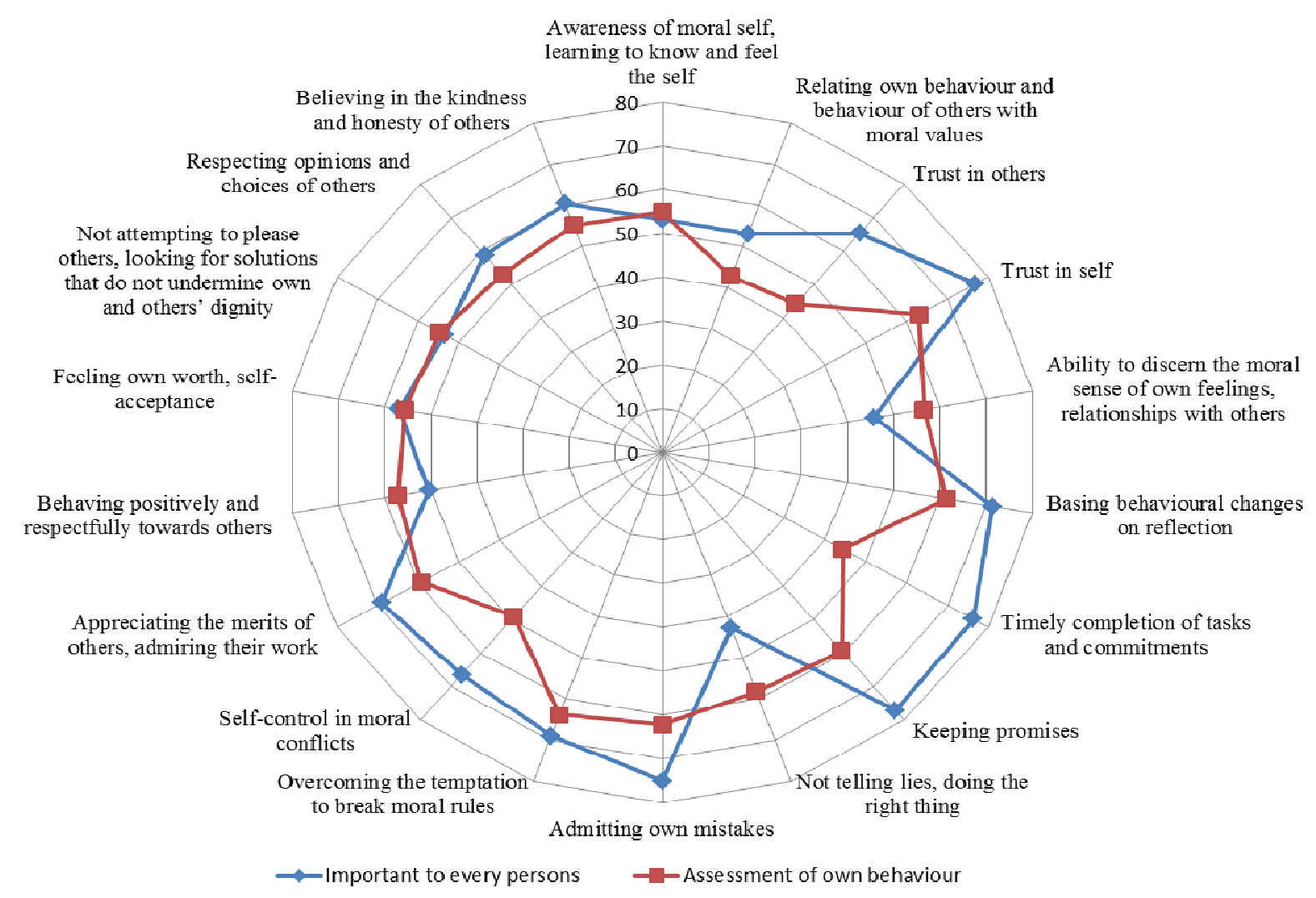

Fig. 1. Distribution of young adolescents' attitudes to their own and others' moral behaviour of $(\%)$

$5-6^{\text {th }}$ graders state that most often they manage to overcome the temptation to break moral rules $(63.9 \%$ of respondents were positive about the statement), rely on themselves $(63 \%)$ and, after reflection, behave better $(61,4 \%)$, acknowledge mistakes $(62,3 \%)$, keep promises $(59,3 \%)$, do the right things $(58,3 \%)$. In other words, more than half of the respondents stated that they do best in behaving with dignity - respecting other people and themselves, being tolerant. Early adolescents also said that they can be dutiful, responsible and honest, take the time to reflect their behaviour, are able to discern the moral sense of their feelings and relationships with others.

Talking about others, early adolescents in certain cases were even more positive, especially in the evaluation of openness (trust in others and self), sense of duty (keeping promises, timely completion of tasks), resilience (self-control, compliance with the rules). However, in assessing the integrity of another person the ratings differed greatly: admitting of being wrong was rated higher in statements about others than in statement about self, whereas telling the truth (not telling lies) was rated obviously lower.

The analysis of the frequency of positive answers to additional statements ("I do not always tell the truth" and "I keep silent if my opinion differs from that of my peers") showed that pupils openly admit hiding the truth or not always tell the truth quite often (Fig. 2). 


\section{SOCIETY. INTEGRATION. EDUCATION. Volume II}

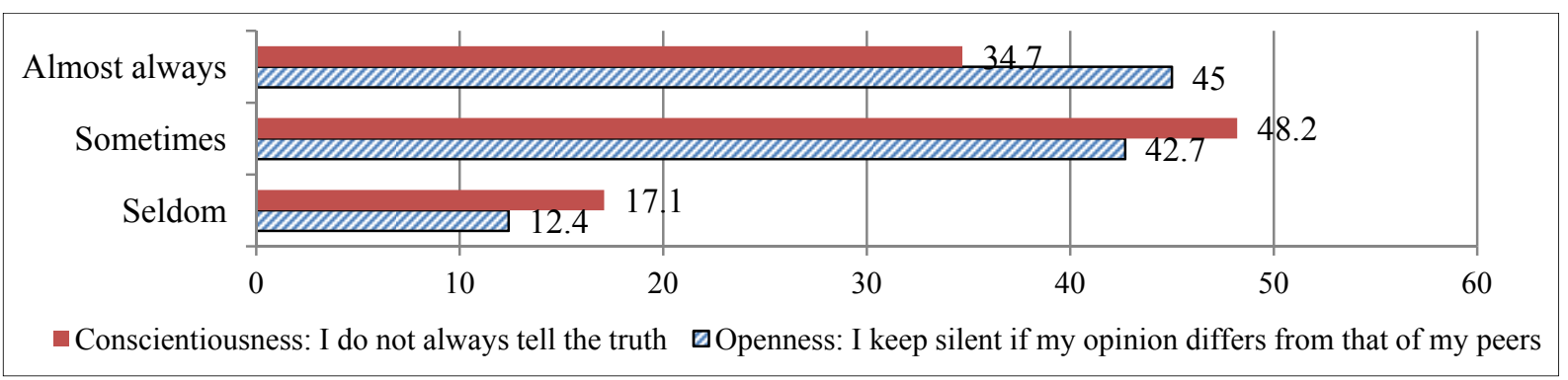

Fig. 2. Conscientiousness and openness in the behaviour of early adolescents (\%)

The analysis of the survey data showed that half of the pupils keep silent if they think differently, and one-third of pupils do not tell the truth very often. Deeper analysis of the frequency of positive answers to the statement "I do not always tell the truth" did not show statistically significant differences by sex, form, selection of ethical education discipline (religion or ethics), participation in school events, and well-being at school. However, statistically significant differences were observed in the frequency of positive answers by academic achievements $(\mathrm{p}=0,019)$, participation in non-formal learning activities $(p=0,035)$ and well-being at home $(p=0,02)$ : pupils with high academic results, who are involved in extracurricular activities, are members of youth organizations and feel well at home more often tell the truth and do not lie. The analysis of the frequency of positive answers to the statement "I keep silent if my opinion differs from that of my peers" revealed a similar trend: statistically significant differences were influenced by academic achievements $(p=0,013)$ and well-being at home $(p=0,043)$, participation in afterschool events $(p=0,048)$ and well-being at school $(\mathrm{p}=0,002)$.

The data analysis leads to the conclusion that pupils tell the truth and do the right things when they feel safe, succeed at school, they are trusted, are involved in favourable and meaningful activities. With positive microclimate at home and at school pupils would learn to understand "the moral being with self", to recognize and feel the self, see the moral meaning of their feelings, be more polite with and more positive towards others. In other words, education of early adolescents should concentrate on the three distinguished moral values authenticity, responsibility and dignity, especially the expression of personhood, reflectiveness, conscientiousness and respect.

\section{Comparison of the attitudes of pupils, their parents and teachers to the behaviour of early adolescents}

The attitude of parents and teachers to the same phenomenon are important for the successful education process. They are the examples that early adolescents try to follow. The attempts of pupils to observe authenticity, responsibility and dignity in their activities were studied in parallel with the survey of their parents and teachers' attitudes. Parents and teachers were asked 
to rate the same statements (empirical characteristics of values) (see Table 1) as the pupils. Graphical representation of the analysed data (Fig. 3) shows significant differences in the attitudes of early adolescents, their parents and teachers.

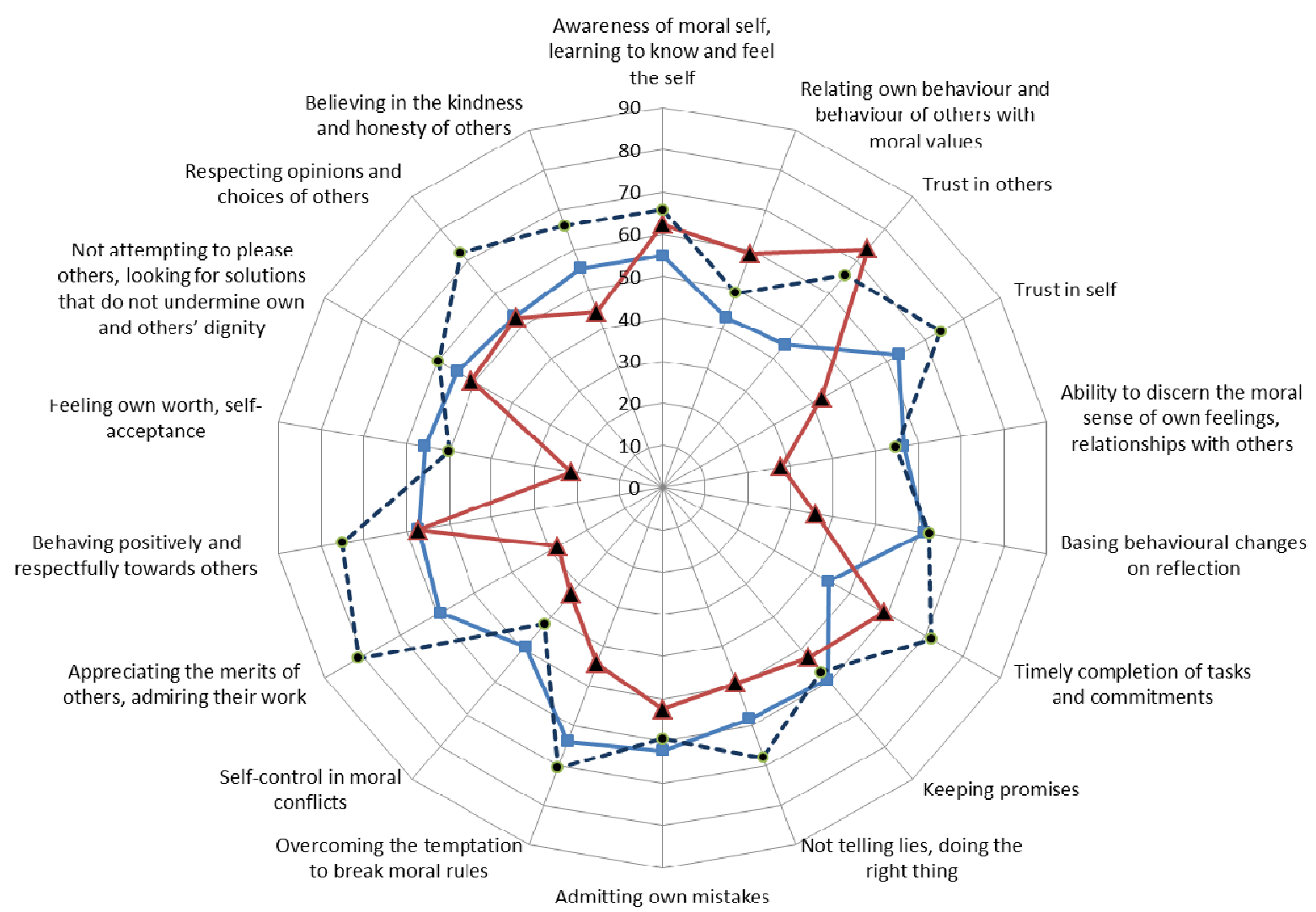

$\longrightarrow$ - Teenagers own behaviour assessment

$\ldots$ Teachers' opinion about students

- - - Parents' opinion about their child

Fig. 3. Distribution of the attitudes of pupils, parents and teachers to the behaviour of early adolescents $(\%)$

The opinions of respondents were the most congruent in the evaluation of four characteristics (expression of values) - awareness of moral self, learning to know and feel the self (personhood), keeping promises (responsibility), admitting making mistakes (conscientiousness), looking for solutions that do not undermine own and others' dignity (dignity). The greatest difference in attitudes was observed in the evaluation of the following characteristics (expression of values): trust in others and in self (openness); timely completion of tasks and commitments (responsibility); appreciating the merits of others, admiring their work (respect); believing in the kindness and honesty of others (tolerance). It should be also noted that parents of early adolescents were more positive than teachers about the moral behaviour of their children. Teachers were especially strict in the evaluation of their pupils' self-esteem, awareness of the moral sense 
of own feelings, relations with others and ability of pupils to appreciate the merits of others, admire their work.

The analysis of the survey results showed that teenagers rather strictly evaluate their own behaviour (Fig. 1). The comparison of the attitudes of $5-6^{\text {th }}$ graders and their teachers showed that teachers rated the moral behaviour of their pupils much lower than the pupils (Fig. 3). These findings encouraged to look deeper into the papers of Lithuanian researchers who study the attitude to moral values, their importance in the education process, the characteristics of modern teachers.

V. Aramavičiūtė and E. Martišauskienè (2014) in their study generalizing the findings of a 10-year survey of moral values in teenagers noted that "in 1999 all teenagers rated their behaviours much lower comparing them to the behaviour important to a spiritual person. In 2009, the respondents gave much higher rates to their faith, spiritual sense of unity, sensitivity to beauty and the search for meaning" (p. 32). However the authors note that the findings require a more detailed research. Yet, the aforementioned study will be helpful for the observation and analysis of moral values configuration in the teenagers of our country.

Literature review revealed information about the change of the role of school and family in the development of pupils' moral values in the modern society: "the role of school in teaching moral values to pupils has increased over the last decade. Especially great attention is given to the teaching of ethics, respect, etiquette" (Žygaitienè, 2011, p. 21). Therefore, the attitudes of teachers to the moral education of pupils have become especially important. A. Galkiene (2011), who analysed the image of the modern teacher, has noted that "pupils obviously feel the person who stands in front of the class; they communicate with the teacher not formally but feeling her/his internal attitude and responding to it" (p. 88). The scholar has also noted that in the opinion of pupils the most important qualities of a teacher are: "ability to understand pupils $<\ldots>$ strive to help other people, insistence and fairness"; early adolescents "most often mention teachers who are ready to help others" (p. 89). Therefore, the teachers should not only be fair and insistent, but also good-willing towards all pupils, believing in the goodness of every pupil "the greatest effect is related with the teacher's attitude" $<\ldots>$ The teacher must see him/herself as the actor ensuring changes" (Hattie, 2001, p. 183).

However, the findings of the study presented above (Fig. 3) show that contemporary teachers are quite strict about their pupils and such position creates an insufficiently favourable environment for the moral development of pupils. On the other hand, the survey findings show the discrepancy of teachers and parents' opinions. Thus we may state the need not only to review the type and level of the relations with pupils at school but also to communicate and collaborate with parents and discuss with them how to achieve the best outcomes of moral personality development. 


\section{Conclusions}

The importance of moral values is increasingly emphasized as an essential condition for the existence of modern man and contemporary society. Scientific papers, strategic documents on education often mention authenticity, responsibility and dignity as the core values in the teaching of morals at school; however in the reality of modern education and downward trends in the recognition of their significance, moral values raise education problems.

The study revealed that modern teenagers are self-confident, obey the rules, analyse their own and their peers' behaviour, often keep promises, i.e. they are responsible, honest, and strive to be authentic. However, responsibility and conscientiousness in their behaviour is not consistent: they tell the truth and do the right things only when they feel safe, successful, trusted, when they are engaged in meaningful activities. Therefore we may state that by creating positive and safe microclimate at school and at home we successfully teach the pupils to understand the "moral sense of self", to be aware of and feel one's true self, perceive the moral sense in own behaviour, i.e. to be authentic, responsible and dignified.

The nature and level of teachers' disposition and attitudes towards pupils is a very important factor in the teaching of morals. The survey revealed that parents of early adolescents rate the moral behaviour of their children much higher than teachers, who very strictly evaluated their pupils' self-esteem, ability to perceive a moral sense in their feelings and relations with others as well as the ability of pupils to appreciate the merits and work of others. Besides, the teachers scored the moral behaviour of teenagers even lower than the pupils. The survey findings lead to the conclusion that such disposition of teachers creates unacceptable learning environment. It is a very complicated problem of modern school that must be dealt with in an integrated manner and at all levels (teacher education, professional development, self- assessment and external reviews).

\section{References}

Aramavičiūtè, V., Martišauskienè, E. (2014). Paauglių vertybių konfigūracija kaip dvasingumo paradigmos išraiška: teorinis ir empirinis aspektai. Acta Paedagogica Vilnensia, 32.

Arendt, H. (1995). Tarp praeities ir ateities. Vilnius: Aidai.

Astra L. (1993). Gyvenimo laikas. Vilnius: Pradai.

Bauman Z. (2007). Globalizacija: pasekmès žmogui. Vilnius: apostrofa.

Budreikaitè, A. (2014). Olimpinio ugdymo ịtaka paauglių dorovinių vertybių raiškai. Tiltai, 62(1), 121-133.

Chambers O. (2011). Viskas Jo šlovei. Apmastymai kiekvienai dienai. Vilnius: Abigailè.

Colombero, G. (2001). Vidinio išgijimo kelias. Vilnius: Katalikų pasaulis.

Donovan, P. (1998). School-based sexuality education: the issues and challenges. Family Planning Perspectives, 188-193.

Galkienè, A. (2011). Šiuolaikinio mokytojo vaizdinys. Pedagogika, (101), 82-90. 


\section{SOCIETY. INTEGRATION. EDUCATION. Volume II}

Girdzijauskas A. (2008). Aukštesniujų klasiu mokiniu dorovinès kultūros ugdymas muzikine veikla. Klaipedos universiteto leidykla

Havard A. (2014). Dora lyderystė. Asmenybès formavimo kelias. Katalikų pasaulio leidiniai.

Hattie J. (2014). Matomas mokymasis. Mokytojo vadovas: kaip užtikrinti kuo didesni poveiki mokymosi pasiekimams. Vilnius: UAB „Petro ofsetas“.

Kaplan, H. B. (1980). Deviant behavior in the defense of self. New York: Academic Press.

Kaplan, H. B. (1986). Social psychology of self-referent behavior. New York: Plenum Press.

Lerner, R. M.; Lerner, J. V.; Almerigi, J. B.; Theokas, Ch.; Phelps, E. et al. (2005). Positive Youth Development, Participation in Community Youth Development Programs, and Community Contributions of Fifth-Grade Adolescents: Findings From the First Wave Of the 4-H Study of Positive Youth Development. The Journal of Early Adolescence. 25 (1): 17-71.

Levi-Straussas (1994). Etika ir begalybè. Vilnius.

Lietuviu kalbos gramatika. (1997). Vilnius.

Lietuvos pažangos strategija „Lietuva 2030“. http://www.lrv.lt/bylos/veikla/2030.pdf

Lileikienè, T. (2004). Būsimųų pedagogų klubo veikla-atrankos ir saviatrankos forma. Pedagogika, (73), 15-24.

Maisonneuve, J. (1973). Introduction à la psychosociologie. Paris: PUF

Martin M. W. (2006). „Moral Creativity“. International Journal of Applied Philosophy, Volume 20, Issue 1, Spring 2006, p. 55-66.

Martišauskienè, E. (2011). Paauglių požiūris ị dvasines vertybes: kaitos tendencijos. Acta Pedagogica Vilnensia, (27), 43-54.

Martišauskienè, E., Aramavičiūtè, V. (2009). Vertybès: švietimo strategijos ir realybè. Pedagogika, (95), 28-35.

Myers, D. G. (2000). Psichologija. Vilnius: Poligrafija ir informatika

Rogers C. R. (2005). Apie tapima asmeniu, Vilnius, Via Recta

Ruškus, J., Sujeta, I. (2011). Moksleivių vaikinų sąmoningumo ugdymas reflektuojant internetinę pornografiją. Acta Pedagogica Vilnensia, (26), 82-95.

Scott D. A. A. Character Education Program: Moral Development, Self-Esteem and At-Risk Youth. http://repository.lib.ncsu.edu/ir/bitstream/1840.16/4535/1/etd.pdf

Silin, J. G. (1995). Sex, Death, and the Education of Children: Our Passion for Ignorance in the Age of AIDS. The Politics of Identity and Education Series. Teacher's College Press

Slee, P. T. (2002). Child, adolescent and family . Cambridge: Cambridge University Press.

Steiner R. (1996). Edocation for adolescents. Eight lectures given to the teachers of the Stuttgart Waldorf School, June 12-19, 1921. Anthropophic press. Žiūrèta per internetą:

Taylor Ch. (1996). Autentiškumo etika. Vilnius.

Thapa, A., Cohen, J., Guffey, S., Higgins-D’Alessandro, A. (2013). A review of school climate research. Review of Educational Research, 83(3), 357-385.

Urban, K. (2003). Towards a componential model of creativity. In D. Ambrose, L. M. Cohen, A. J. Tannenbaum (Eds.), Creative intelligence: Toward theoretic integration. Cresskill, NJ: Hampton Press. p. 81-112.

Virbalienè, A. (2006). Paauglių orumo ugdymasis, kaip moralinio brendimo sąlyga. Tiltai. (4), 121-132.

Žygaitienè, B. (2011). Būsimų technologijų mokytojų požiūrio ị dorovines vertybes kaitos tendencijos. Pedagogika, (103), 15-22. 